Acta vet. scand. $1960,1,105-113$.

From the Institute of Sterility Research, The Royal Veterinary and Agricultural College, Department of Obstetrics and Gynaecology, Copenhagen.

\title{
THE COMPARATIVE EFFICIENCY OF THE INTRACERVICAL AND INTRAUTERINE INSEMINATION \\ OF CATTLE WITH STREPTOMYCIN-TREATED AND NON-TREATED SEMEN
}

By

H. C. Adler.

The significance for the breeding efficiency of the site of semen deposition in the bovine genital tract has been investigated by several research workers such as Knight et al. (1951), Salisbury \& VanDemark (1951, 1952), VanDemark (1952), Stewart (1952), Stewart \& Melrose (1952) and Inger (1955). By using the rectal-fixation procedure similar conception rates were obtained, whether the semen was deposited in the cervical canal or the uterine corpus or cornua.

Consequently intracervical insemination has been recommended based on the following arguments; there is no mechanical penetration through the cervix which supposedly forms a barrier against infection; no traumatic damage of the uterus itself is possible; the insemination is more easily carried out, especially by less experienced technicians; and finally, in the case of the insemination of a pregnant cow by such personnel, intracervical insemination will in most cases not interrupt the pregnancy, whereas foetal damage generally will result from intrauterine insemination, VanDemark et al. (1952), Stewart (1952) and Stewart \& Melrose (1952).

On this basis the standard procedure in this country has for several years been intracervical insemination, whereas the majo- 
rity of A.I.-workers preferred intrauterine insemination during the first years of artificial insemination.

In the cited investigations the semen diluent was egg yolk citrate, and most commonly no antibiotics were added. However, at present cream is extensively used in this country as a semen diluent, Pedersen (1954) and Adler \& Rasbech (1956). Moreover, streptomycin is added, and it might be thought that the effect of this antibiotic can vary in the cervix and uterus when taking into account that the rate of resorption is different in those two parts of the genital tract, Adler \& Szabo (1952). Furthermore, it has been demonstrated that the added streptomycin - at least under certain conditions - is supposed to be antibacterially effective only after the diluted semen has been introduced into the genital organs, Adler (1957). Consequently, with the use of the more recent diluents, the writer has considered it necessary to investigate the significance of the site of semen deposition.

\section{MATERIAL AND METHOD}

The experiment took place in Møens kvægavlsforening (A.I.centre ${ }^{1}$ ) from October 1955 to December 1956. In this period all first-inseminations in two districts of the centre were carried out according to the intracervical or intrauterine procedure. In both cases the rectal-fixation method was used and the two veterinarians doing the breeding alternated their method with each first service - intracervical on one and intrauterine on the next.

The semen was collected from bulls of Red Danish Milkbreed belonging to the centre and all of them free from genital vibriosis. The dilution took place immediately after collection. Each ejaculate was divided into two portions, each of which was extended to the same dilution rate with homogenized, sterilized cream (9 \% fat). One portion was treated with $1000 \mu \mathrm{g}$. of dihydrostreptomycin per $\mathrm{ml}$. of cream, and the other portion was untreated. In one week all inseminations in one district were performed with streptomycin-treated semen, in the other district with untreated semen; the following week vice versa, etc. The $60-90$ day non-return percentage was calculated and used as an expression of the breeding efficiency.

1) The author wishes to thank the veterinarians Dagnæs-Hansen. Kaj Jensen and Geert-Jørgensen for their cooperation. 


\section{RESULTS}

The non-return rates which were obtained for each individual bull and for the material as a whole are shown in table 1 and further illustrated in fig. 1.

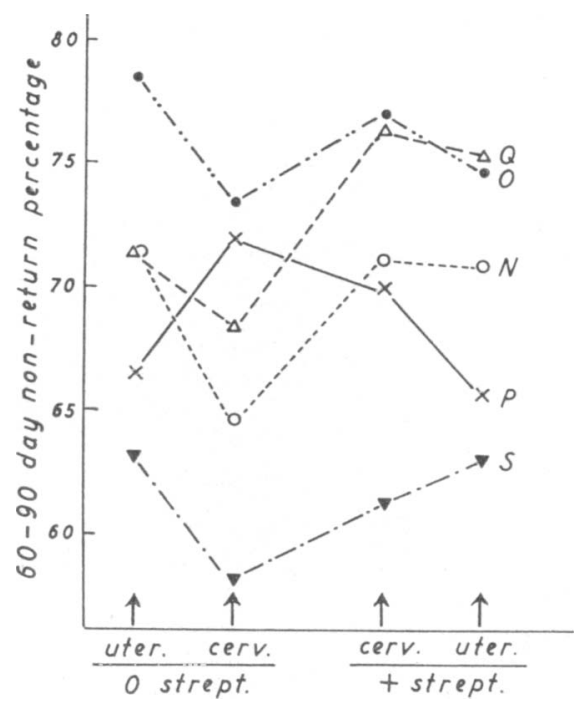

F i g. 1. Non-return rates of each individual bull in the four experimental groups.

Table 1. Breeding efficiency (60-90 day non-return percentage) from uterine and cervical insemination with streptomycin-treated and non-treated semen.

\begin{tabular}{|c|c|c|c|c|c|c|c|c|}
\hline \multirow{3}{*}{ Bull } & \multicolumn{4}{|c|}{ o strept. } & \multicolumn{4}{|c|}{ + strept. } \\
\hline & \multicolumn{2}{|c|}{ uterine ins } & \multicolumn{2}{|c|}{ cerv. ins. } & \multicolumn{2}{|c|}{ cerv. ins. } & \multicolumn{2}{|c|}{ uterine ins. } \\
\hline & $\begin{array}{c}\text { No. } \\
\text { l. ins. }\end{array}$ & $\begin{array}{c}\% \\
\text { N. R. }\end{array}$ & \begin{tabular}{|c|} 
No. \\
I. ins.
\end{tabular} & $\begin{array}{l}\% \\
\text { N. } 1 \text {. }\end{array}$ & $\begin{array}{c}\text { No. } \\
\text { l. ins. }\end{array}$ & $\begin{array}{c}\% \\
\text { N. R. }\end{array}$ & $\begin{array}{c}\text { No. } \\
\text { l. ins }\end{array}$ & $\begin{array}{r}\% \\
\text { N. } 1 \text {. }\end{array}$ \\
\hline $\begin{array}{l}\text { N. } \\
\text { O. } \\
\text { P. } \\
\text { Q. } \\
\text { S. }\end{array}$ & $\begin{array}{l}348 \\
362 \\
230 \\
597 \\
257\end{array}$ & $\begin{array}{l}71.3 \\
78.5 \\
665 \\
71.2 \\
63.0\end{array}$ & $\begin{array}{l}372 \\
338 \\
242 \\
687 \\
215\end{array}$ & $\begin{array}{l}64.5 \\
73.4 \\
71.9 \\
68.4 \\
58.1\end{array}$ & $\begin{array}{l}374 \\
348 \\
215 \\
595 \\
216\end{array}$ & $\begin{array}{l}71.1 \\
77.0 \\
69.8 \\
76.1 \\
61.1\end{array}$ & $\begin{array}{l}343 \\
368 \\
226 \\
657 \\
191\end{array}$ & $\begin{array}{l}70.8 \\
74.7 \\
65.5 \\
75.3 \\
62.8\end{array}$ \\
\hline Total & 1794 & 70.9 & 1854 & 67.8 & 1748 & 72.6 & 1785 & 71.8 \\
\hline
\end{tabular}

It will be seen that the results for four bulls $(\mathrm{N}, \mathrm{O}, \mathrm{Q}$ and $\mathrm{S}$ ) are approximately analogous in the four experimental groups, however at different levels, the percentages indicating that with no streptomycin added, uterine insemination has resulted in a 
higher breeding efficiency than cervical insemination; and that addition of streptomycin has improved the results obtained by cervical, but not by uterine insemination. The results of the bull $P$ are placed in the four experimental groups in a different way.

The analysis of variance ${ }^{1}$ ) shown in tables 2 and 3 is computed on the quantity $x=2$ arcsin $\sqrt{h}$, as the variance of $x$ contrary to the variance of $h$ is independent of the magnitude of the probability $p$. Moreover, the distribution of $x$ can be supposed to be approximately normal about $2 \arcsin \sqrt{p}$ with the variance $n$ (the number of cows which form the basis for the calculation of $h$ in the single groups). In the analysis of the transformed

T a ble 2. $2 \cdot \arcsin \sqrt{\mathrm{h}}$.

\begin{tabular}{cccccc}
\hline \multirow{2}{*}{ Bull } & \multicolumn{2}{c}{ Cerv. ins. } & \multicolumn{2}{c}{ Uterine ins. } & \multirow{2}{*}{ Average } \\
& + strept. & 0 strept. & + strept. & 0 strept. & \\
\hline N. & 2.0064 & 1.8650 & 1.9998 & 2.0109 & 1.9693 \\
O. & 2.1412 & 2.0578 & 2.0875 & 2.1773 & 2.1166 \\
P. & 1.9780 & 2.0242 & 1.8860 & 1.9071 & 1.9496 \\
Q. & 2.1200 & 1.9477 & 2.1013 & 2.0087 & 2.0423 \\
S. & 1.7947 & 1.7335 & 1.8297 & 1.8338 & 1.7988 \\
Average & 2.0423 & 1.9363 & 2.0226 & 2.0051 & 2.0007 \\
\hline
\end{tabular}

Table 3. Analysis of variance.

\begin{tabular}{|c|c|c|c|c|c|}
\hline & & $\begin{array}{l}\text { Sum of } \\
\text { squares }\end{array}$ & $\begin{array}{l}\text { Degrees of } \\
\text { freedom }\end{array}$ & Variance & Percentile \\
\hline \multirow{3}{*}{ 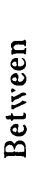 } & bulls & $63.03 \tilde{3}$ & 4 & 15.78 & $99.95 \ll$ \\
\hline & $\begin{array}{l}\text { uter.ins. } \\
\text { cerv.ins. }\end{array}$ & 1.223 & 1 & 1.22 & $70-80$ \\
\hline & ${ }_{0}^{+}$strept. & 6.946 & 1 & 6.95 & $99.0-99.5$ \\
\hline \multirow{4}{*}{ 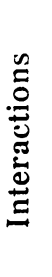 } & bulls $\sim$ uter. ins. & 5.093 & 4 & 1.27 & $70-80$ \\
\hline & bulls $\sim{ }_{0}^{+}$strept. & 6.534 & 4 & 1.63 & $80-90$ \\
\hline & $\begin{array}{l}\text { uter.ins. } \sim \sim_{0}^{+} \text {strept. } \\
\text { cerv.ins. }\end{array}$ & 3.426 & 1 & 3.43 & $90-9 \overline{3}$ \\
\hline & bulls $\sim \underset{\text { cerv.ins. }}{\text { uter. ins. }} \sim_{n}^{+}$strept. & 2.254 & 4 & 0.56 & $30-40$ \\
\hline \multicolumn{2}{|c|}{ Total } & 88.511 & 19 & & \\
\hline
\end{tabular}

1) The statistical evaluation of the material has been made by $\mathrm{Mr}$. Arne Nielsen, actuary. 
values $\mathrm{x}$ in table 3 no dependence has been found between the three factors; the bull, the streptomycin addition and the site of semen deposition. Concerning the interaction between the two last mentioned factors the variation is rather great, but not significantly greather than presupposed, (theoretic variance equals the sum of squares $\chi^{2}$-distributed) corresponding with that addition of streptomycin has been effective in connection with cervical but not - or in any case to a smaller degree with uterine insemination. Nor are the interactions between the bull and the site of semen deposition, and between the bull and the streptomycin addition significant. The percentiles are rather high, probably due to the deviations of the bull $P$.

Furthermore, it will be seen that the variation between the group with streptomycin and the group without streptomycin is significant at the 1 pct. level, whereas there is no significance for the variation between the cervical and the uterine insemination. As the interaction between those two factors corresponds to a fairly high percentile and on the basis of the non-return percentages it can be concluded that cervical insemination with streptomycin-treated semen has caused a significantly higher non-return percentage than cervical insemination with untreated semen, whereas it cannot be said to have been the case for uterine insemination.

From this it follows that with untreated semen uterine insemination has resulted in a better non-return percentage than cervical insemination, even though statistical significance has not been found.

Finally, the analysis shows that relatively the greatest variation has been found between the bulls.

\section{DISCUSSION}

Addition of streptomycin to diluted semen has two effects; an antibacterial one which, to a certain degree, is exerted after the insemination, Adler (1957); and a slightly antifertile one which probably can be attributed to a certain sperm-toxicity, Adler, Lange \& Rasbech (1952) and Adler \& Rasbech (1952).

The first mentioned effect, under certain circumstances, is supposed to have a tendency to improve the breeding efficiency; while the last mentioned effect has a tendency to cause a slight reduction. Therefore, a demonstration of increasing or decreasing fertility, will depend here on which effect has been the dominant. 
The results of this investigation can be explained in the following way for the four bulls, the non-return rates of which are approximately analogous in the four experimental groups.

By intrauterine insemination a breeding efficiency can be obtained which is a little higher than by intracervical insemination which in this experiment has resulted in a better nonreturn percentage by intrauterine insemination than by intracervical insemination when non-treated semen has been used.

By uterine insemination of streptomycin-treated semen the antibacterial effect manifests itself to a minor degree (because of rapid resorption) as compared to the sperm-toxic effect, explaining that in the experiment streptomycin-treatment of the semen did not improve the non-return rate by uterine insemination, whereas the antibacterial effect of the streptomycin by cervical insemination (because of a more retarded resorption) is predominant as compared to the sperm-toxic effect; explaining that in connection with cervical insemination in the experiment the streptomycin-treatment of the semen did increase the nonreturn rate up to the level obtained by uterine insemination.

The record of the bull $P$ seems not to be in immediate accordance to this. However, it might be supposed that the semen of this bull has contained a fertility-depressing principle which has not at all, or only to a minor extent, been streptomycin-susceptible and which has manifested itself to a higher degree in the uterus than in the cervix, explaining that this bull in the experiment has yielded the best results with non-treated semen applied intracervically and that streptomycin-treatment (because of predominantly sperm-toxic effect) has decreased the conception rate in connection with both cervical and uterine insemination.

\section{CONCLUSIONS}

With homogenized, sterilized cream as diluent for bovine semen it can generally be expected:

1. That intrauterine inseminations without addition of antibiotics to the semen will yield a breeding efficiency which is a little better than intracervical inseminations.

2. That streptomycin-treatment of the semen will improve the breeding efficiency in connection with intracervical insemination, but not by intrauterine insemination. 


\section{LITERATURE}

Adler, H. C.: Genital Vibriosis in the Bovine. København 1957. (Diss.) Adler, H. C., Merete Lange \& N. O. Rasbech: Nord. Vet.-Med. 1952, 4, 397.

Adler, H. C. \& N. O. Rasbech: Nord. Vet.-Med. 1952, 4, 604.

Adler, H. C. \& N. O. Rasbech: Nord. Vet.-Med. 1956, 8, 497.

Adler, H. C. \& L. Szabo: 1952. Unpublished data.

Inger, E.: Vergleichende Untersuchungen über die intrauterine, cervicale und vaginale Sameneinführung beim Rind. Hannover 1955. (Diss.)

Knight, C. W,. T. E. Patrick, H. W. Anderson \& Cecil Branton: J. Dairy Sci. 1951, 34, 199.

Pedersen, K. E.: Ugeskr. Landm. 1954, 99, 742.

Salisbury, G. W. \& N. L. VanDemark: J. Dairy Sci. 1951, 34, 68.

Salisbury, G. W. \& N. L. VanDemark: Report of The II International Congress of Physiology and Pathology of Animal Reproduction and of Artificial Insemination, Copenhagen 1952, vol. III, 99.

Stewart, D. L.: Ibid. 1952, vol. III, 107.

Stewart, D. L. \& D. R. Melrose: Vet. Rec. 1952, 64, 605.

VanDemark, N. L.: Corn. Vet. 1952, 42, 215.

VanDemark, N. L., G. W. Salisbury \& L. E. Boley: J. Dairy Sci. 1952, $35,219$.

\section{SUMMARY}

The experiment took place during a period of 15 months at an A.I.-centre, where all the ejaculates collected were split into two portions and diluted with homogenized, sterilized cream and the same $+1000 \mu \mathrm{g}$. of streptomycin $/ \mathrm{ml}$. respectively. For one week the streptomycin-treated semen was used in one district of the centre, the untreated semen in another district, the next week vice versa and so on. In the same two districts every other first-insemination was performed intrauterinely, every other intracervically, in both cases using the rectal-fixation method. Based on the first-inseminations the $60-90$ day non-return percentage was calculated.

For four bulls the breeding efficiency in the four experimental groups were almost analogous, however at various levels (table 1 and fig. 1), uterine insemination without streptomycin resulting in a higher non-return rate than cervical insemination with untreated semen, and streptomycin-treated semen giving a higher conception rate in connection with cervical insemination only. The results of one bull differed from this.

The data are used for statistical calculation and evaluation (table 2 and 3 ), and it is discussed how the results may be explained by supposing that one effect of the streptomycin, the antibacterial, has less possibility in connection with intrauterine insemination than with intracervical insemination, the streptomycin being resorbed 
faster and more slowly, respectively, whereas the slight sperm-toxicity has been effective in both cases, resulting in an increased breeding efficiency in connection with intracervical insemination only.

It is concluded that commonly intrauterine insemination with semen diluted with cream without addition of antibiotics results in a conception rate which is a little higher than what can be obtained with intracervical insemination. Furthermore, that streptomycintreatment of the semen improves the results at intracervical but not at intrauterine insemination.

\section{ZUSAMMENFASSUNG}

Die komparative Befruchtungsleistung der intracervikalen und intrauterinen Insemination von Rindern mit Streptomycin-behandeltem und nichtbehandeltem Samen.

In einem Rinderzuchtverein mit künstlicher Besamung wurden in einer Periode von 15 Monaten alle Ejakulate in zwei Hälften geteilt und mit homogenisierter, sterilisierter Sahne beziehungsweise mit Sahne verdünnt, der $1000 \mu \mathrm{g}$ Streptomycin pro ml zugesetzt waren. Abwechselnd wurde der so verdünnte Samen in zwei Distrikten des Vereins angewandt, wo ausserdem jede zweite Besamung intracervikal und jede zweite Insemination intrauterin geschah. Das Nichtumrindernprozent nach 60-90 Tage dieser Erst-Inseminationen wurde festgelegt.

Bei vier Bullen wurden ungefähr parallele Befruchtungsresultate erzielt, indem die uterine Insemination ohne Streptomycin ein höheres Nichtumrindernprozent ergab als die cervikale Besamung ohne Streptomycin, und streptomycinbehandelter Samen allein bei cervikaler Insemination ein höheres Nichtumrindernprozent zeitigte als unbehandelter Samen. Die Resultate eines Bulles wichen hiervon ab.

Die Daten des Versuches werden statistisch bewertet, und es wird diskutiert, ob sich der Ausfall des Experimentes durch die Annahme erklären lasse, dass die eine Wirkung des Streptomycins, die antimikrobielle, eine geringere Möglichkeit gehabt habe, sich bei uteriner als bei cervikaler Insemination geltend zu machen, wo das Streptomycin schneller beziehungsweise langsamer resorbiert wird, während die schwach spermienschädigende Wirkung in beiden Fällen zur Geltung kam, so dass die Streptomycinbehandlung nur bei intracervikaler Insemination die Befruchtungseffektivität $\mathrm{zu}$ verbessern vermochte.

Es wird die Schlussfolgerung gezogen, dass die intrauterine Insemination mit nicht-antibiotikabehandeltem, mit Sahne verdünntem Samen im allgemeinen etwas höhere Befruchtungsresultate als die intracervikale Besamung ergibt, und dass eine Streptomycinbehandlung des Samens die Ergebnisse bei intracervikaler, aber nicht bei intrauteriner Insemination verbessert. 


\section{SAMMENFATNING}

Befrugtningseffektiviteten ved intracervikal og intrauterin insemination af kvæg med streptomycinbehandlet og ikke antibiotikabehandlet sæd.

I en kvægavlsforening med kunstig sædoverf $\varnothing$ ring foretoges $\mathrm{i}$ en periode på 15 måneder todeling af alle ejakulater og fortynding med henholdsvis homogeniseret, steriliseret fløde og fløde tilsat $1000 \mu \mathrm{g}$ streptomycin pr. ml. På skift anvendtes den således fortyndede sæd i to af foreningens distrikter, hvor desuden hver anden insemination udførtes intracervikalt, hver anden intrauterint. Disse f $\varnothing$ rste-inseminationers $60-90$ dages ikke-omløberprocent blev opgjort.

Der opnåedes for fire tyres vedkommende omtrent parallelle befrugtningsresultater, idet uterin insemination uden streptomycin gav højere ikke-omløberprocent end cervikal insemination uden streptomycin, og streptomycinbehandlet sæd alene ved cervikal insemination gav højere ikke-omløberprocent end ubehandlet sæd. Een tyrs resultater var afvigende herfra.

Fors $\phi$ gets data vurderes statistisk, og det diskuteres, hvorledes eksperimentets udfald kan tænkes forklaret ved antagelse af, at streptomycinets ene virkning, den antimikrobielle, har haft ringere mulighed for at gøre sig gældende ved uterin end ved cervikal insemination, hvor streptomycinet resorberes henholdsvis hurtigere og langsommere, medens den svagt spermiebeskadigende virkning har gjort sig gældende i begge tilfælde, således at streptomycinbehandlingen kun har kunnet forbedre befrugtningseffektiviteten ved intracervikal insemination.

Det konkluderes, at intrauterin insemination med ikke-antibiotikabehandlet sæd fortyndet med fløde i almindelighed giver lidt højere befrugtningsresultater end intracervikal insemination, og at streptomycinbehandling af sæden forbedrer resultaterne ved intracervikal, men ikke ved intrauterin insemination.

(Received July 7. 1958). 